\title{
Direitos fundamentais e sua proteção no direito brasileiro e na convenção americana
}

\author{
Plínio de Oliveira Corrêa Filho* \\ Plínio de Oliveira Corrêa**
}

\section{SÍNTESE EVOLUTIVA}

A expressão direitos humanos - segundo Jean Imbert, Professor e Pesquisador da Universidade de Paris ${ }^{1}$ - embora tivesse sido utilizada vagamente pela primeira vez no século XVI por um escritor latino, remonta ao Código de Hamurabi, como demonstra Marcus Helmons, Professor de Direito na Universidade Católica de Louvain. ${ }^{2}$

Os direitos da pessoa humana - também denominados de "direitos humanos", "garantias individuais", "liberdades públicas"e "direitos fundamentais"
- estão elencados exemplificativamente em inúmeros documentos da História do Direito, que marcaram e acompanharam a evolução da Sociedade no último milênio da Era de Peixes do novo calendário da Humanidade.

Com efeito, dentre tantos documentos internacionais, protetores dos direitos individuais, cabe relembrar ${ }^{3}$ a Carta de Henrique I, da Inglaterra, em 1100; o Estatuto da Paz, firmado pelo Rei Luiz VI, que reinou na França de 1108 a 1137; a Magna Carta, assinada no Campo de Runnymead, em plena batalha, nas cercanias do Tâmisa, em 15 de junho de

\footnotetext{
*Bacharel em Ciências Jurídicas e Sociais pela Faculdade de Direito da URGS; especialização em Ciências Penais pela mesma Instituição.

**Diretor da Faculdade de Direito da UFRGS, Professor de Processo Penal na Faculdade de Direito da UFRGS.

1 IMBERT, Jean. Les Droits de l'Homme en France. Paris: La Documentation Française, 1985. (Coleção Notes et Études Documentaires). p. 7.

2 HELMONS, Marcus. Mélanges Offerts à Georges Levasseur: droit pénal, droit européen. Paris: Litec, 1992. p. 227.

3 CORRÊA, Plínio de Oliveira. Liberdade Individual nos Países do Mercosul. 2. ed. Porto Alegre: Livraria do Advogado, 1998. p. 21 et seq.
} 
1215; a Declaração Inglesa de Direitos, de 1689; a Declaração da Independência Americana, de 04 de julho de 1776 (resultante das anteriores Declaração de Direitos da Virgínia e das Constituições de Connecticut, da Pensilvânia, de Mariland e da Carolina do Norte); a Declaração Francesa dos Direitos do Homem e do Cidadão, de 02 de outubro de 1789; a Carta das Nações Unidas, assinada no dia 26 de junho de 1945, na cidade de São Francisco, da Califórnia; a Declaração Americana dos Direitos e Deveres do Homem, firmada em Bogotá, no dia 02 de maio de 1948; a Declaração Universal dos Direitos do Homem, da ONU, celebrada em Paris no dia 10 de dezembro de 1948; o Convênio de Proteção dos Direitos Humanos e das Liberdades Fundamentais, de Strasburgo, assinado em Roma, no dia 04 de novembro de 1950 e promovido pelo Conselho da Europa; a Proclamação de Teerã Sobre Direitos Humanos, em 1968, adotada pelo plenário da I Conferência Mundial dos Direitos Humanos da ONU; a Convenção Americana Sobre Direitos Humanos, levada a efeito na cidade de São José, Costa Rica, a 22 de novembro de 1969; a Carta Africana dos Direitos Humanos e dos Povos, ocorrida em Nairóbi, em 26 de junho de 1981; a Declaração de Viena, de 25 de junho de 1993, com participação de mais de 170 países.

Entrementes, a inserção do Brasil na tutela dos direitos da pessoa humana, como lembra Cançado Trindade, ${ }^{4}$ tem se verificado tanto pela adesão quanto pela ratificação de Tratados Internacionais voltados não só para os aspectos gerais, mas também pontuais, a saber: Convenção sobre Asilo, de 1928 (que entrou em vigor a 03.09.1929); Convenção sobre Asilo Político, de 1933 (23.02.1937); Convenção Interamericana sobre Concessão dos Direitos Civis à Mulher, de 1948 (19.03.1952); Convenção Interamericana sobre Concessão dos Direitos Políticos à Mulher, de 1948 (21.03.1950); Convenção para a Prevenção e a Repressão do Crime de Genocídio, de 1948 (15.04.1952); Convenção sobre os Direitos Políticos da Mulher, de 1952 (13.08.1963); Convenção sobre Asilo Diplomático, de 1954 (17.09.1957); Convenção sobre Asilo Territorial; de 1954 (14.01.1965); Convenção Relativa à Luta contra a Discriminação no Campo do Ensino, de 1960 (19.04.1968); Convenção Internacional sobre a Eliminação de Todas as Formas de Discriminação Racial, de 1965 (27.03.1968); Convenção sobre a Eliminação da Todas as Formas de Discriminação contra a Mulher, de 1979 (01.02.1984); Convenção Interamericana para Prevenir e Punir a Tortura, de 1985 (20.07.1989); Convenção das Nações Unidas contra a Tortura e Outros Tratamentos ou Penas Cruéis, Desumanos ou Degradantes de 1984 (28.09.1989); e Convenção das Nações Unidas sobre os Direitos da Criança, de 1989 (24.09.1990); além das ratificações de 48 Convenções da Organização Internacional do Trabalho até 1990.

4 TRINDADE, Antônio Augusto Cançado. A Proteção Internacional dos Direitos Humanos e o Brasil, 2. ed. s.1.: Humanidades. p. 63-64. 
Com exceção da Declaração Inglesa de Direitos, ${ }^{5}$ de 1689, que restaurava normas costumeiras de direito positivo, todas as outras são, em regra, apenas declarações de princípios e recomendações aos governantes, válidas para todos os povos em todas as épocas, como pregou Cícero ${ }^{6}$ na antiga Roma, referindo-se à verdadeira lei, e como destacou Mirabeau perante a Assembléia Nacional Constituinte, quando da aprovação da Declaração de 1789 , que serviu de preâmbulo à Constituição Revolucionária mas que só recentemente, no governo Mitterrand, foi incorporada por referendum popular ao direito positivo francês.

Paralelamente, várias Convenções regionais de proteção aos direitos humanos, ora civis e políticos, ora econômicos, sociais e culturais, foram surgindo. Todavia, somente com o advento das citadas Convenção Européia de Direitos Humanos, de 4 de novembro de 1950 (que passou a vigorar na ordem internacional em 3 de setembro de 1953), Convenção Americana sobre Direitos Humanos de 1969 (com vigência a partir de 18 de julho de 1978 , na conformidade do parágrafo $2^{\circ}$ do art. 74), e Carta Africana de Direitos Humanos e dos Povos de 1981 (que entrou em vigor a 21 de outubro de 1986 , nos termos do parágrafo $2^{\circ}$ do art. 63), é que se iniciou, efetivamente, o processo da tutela judicial internacional dos direitos humanos e, assim mesmo, com alguma resistência em nome da soberania de cada Nação ou de cada Estado.
A iniciativa desse processo, como já se frisou, coube à Convenção Européia de Direitos Humanos, dentro do Conselho Europeu, seguida pela Convenção Interamericana dos Direitos Humanos, no âmbito da Organização dos Estados Americanos, pela Carta Africana dos Direitos Humanos e dos Povos, levada a efeito pela Organização da Unidade Africana (OUA), e culminou com a Declaração de Viena e seu Programa de Ação, reafirmando a universalização dos direitos humanos e legitimidade da preocupação internacional com o tema.

Com efeito, tanto a citada Convenção Européia, quanto a mencionada Convenção Interamericana e a referida Carta Africana, embora se limitando a proteger os chamados direitos civis e políticos, incluindo-se, aí, as garantias processuais básicas, - criaram para os respectivos Estados a possibilidade de aderir às cláusulas que instituem a competência de um Tribunal Supraconstitucional de Julgamento das violações de direitos pelos Estados-membros.

Para tanto, as aludidas convenções previram duas espécies de remédios processuais: o recurso individual, que é aquele interposto pelo(s) interessado(s) pessoa(s) física(s) contra o Estado, e o recurso estatal, consistindo na interposição por um Estado contra outro na defesa de um cidadão ou de um grupo de cidadãos.

A Corte Européia tem sede em Strasbourg, na França, a Americana, nas Américas, em São José da Costa Rica, e

5 "Os Lordes espirituais e temporais e os Membros da Câmara dos Comuns declaram, desde logo, o seguinte: ...".

6 CÍCERO. De la République de Lois. s.1.: Garmier-Flammarion, 1965. p. 86, XXII. 
a Africana, na África, na cidade de Nairóbi, funcionando, todas, como última instância de julgamento para quaisquer dos direitos fundamentais consagrados pelas respectivas convenções, isto é, em qualquer processo judicial de natureza penal ou civil, para os países que ratificarem ou aderirem à sua jurisdição.

Os diferentes procedimentos adotados pelas Cortes de Strasbourg, de São José e de Nairóbi, estão regulados, pormenorizadamente, nas citadas convenções e nos seus respectivos regimentos. Cabe registrar, porém, que a escolha dos membros que compõem, respectivamente, a Comissão, o Comitê ou a Corte obedece a critérios judiciosos de representatividade, isenção, idoneidade e notório saber jurídico, gozando de imunidade e garantias necessárias para o pleno exercício de suas elevadas e imprescindíveis funções.

\section{CONSTITUIÇÃO BRASILEIRA DE 1988}

As aspirações francesas de $1789, l i$ berdade, igualdade e fraternidade, correspondem, respectivamente, a etapas evolutivas dos direitos fundamentais de primeira, de segunda e de terceira gerações: enquanto o Estado absolutista cedeu espaço ao Estado liberal, garantindo as liberdades públicas e individuais e projetando os direitos civis e políticos, já apregoados por Locke e Grotius; o Estado de Direito, inicialmente moldado pela filosofia liberal e pelo laisser faire laisser passer, reconheceu, mais tarde, pelo Estado Democrático de Direito, a necessidade de implementar o direito de igualdade de oportunidade aos cidadãos no âmbito dos direitos sociais, dando lugar à fraternidade solidária, para que a máquina estatal, outrora omissa e indiferente, assumisse, ainda que tardiamente, compromissos solenes e impostergáveis de estabelecer políticas públicas destinadas não apenas em assegurar a liberdade, mas eliminar as desigualdades sociais e promover fraternalmente, em todos os setores, a dignidade da pessoa humana ${ }^{7} \mathrm{em}$ sua integralidade, ${ }^{8}$ promovendo, assim, o bem comum, isto é, proporcionar os meios necessários para se atingir os fins humanos enquanto a vida é convívio."

Com efeito, a Assembléia Nacional Constituinte, invocando a proteção de Deus, instituiu o Estado Democrático de Direito, "destinado a assegurar o exercício dos direitos sociais e individuais, a liberdade, a segurança, o bem-estar, o desenvolvimento, a igualdade e a justiça como valores supremos de uma sociedade fraterna, pluralista e sem preconceitos, fundada na harmonia social e comprometida, na ordem interna e internacional, com a solução pacífica das controvérsias," ${ }^{10}$ promulgando, em 5 de

7 ZAVASCKI, Teori Albino. in Revista da Faculdade de Direito da UFRGS, 15/230, Síntese, 1998.

8 JOÃO XXIII. Encíclica Mater et Magistra, 1961.

9 CORRÊA, Plínio de Oliveira. A Provocação Jurisdicional. Porto Alegre; Editora da Universidade, 1978. p. 11.

10 Preâmbulo da Constituição Federal de 1988. 
outubro de 1988, a atual Constituição da República Federativa do Brasil.

Eis porque a vigente Constituição Brasileira - a exemplo das anteriores Cartas Políticas, de 1824, 1891, 1934, 1937, 1946, 1967 e 1969 - tem um capítulo reservado aos direitos fundamentais, reiterando no seu artigo $5^{\circ}$ que "todos são iguais perante a lei, sem distinção de qualquer natureza, garantindo-se aos brasileiros e aos estrangeiros residentes no País a inviolabilidade do direito à vida, à liberdade, à igualdade, à segurança e à propriedade". E dentre os princípios fundamentais da Constituição, sobre os quais se assenta o Estado Brasileiro, - estão a cidadania, a dignidade da pessoa humana e a prevalência dos direitos humanos."

Assim, o Capítulo I, do Título II, que trata Dos Direitos e Garantias Fundamentais da nossa lei maior, assegura preventivamente aos homens e mulheres, em geral, e, concretamente, aos acusados, aos condenados, aos internados, às vítimas e às testemunhas nas áreas do Direito Penal e do Processo Penal, estes princípios constitucionais:

1) Anterioridade e legalidade da lei penal: não há crime sem lei anterior que o defina, nem pena sem prévia cominação legal.

2) Personalidade da pena: a lei regulará a individualização da pena e adotará, entre outras, as seguintes: a) privação ou restrição de liberdade; b) perda de bens; c) multa; d) prestação social alternativa; e)suspensão ou interdição dos direitos.
3) Proibição das penas: a) de morte, salvo em caso de guerra declarada, nos termos do art. 84, XIX; b) de caráter perpétuo; c) de trabalhos forçados; d) de banimento; e) cruéis.

4) Prisão somente em caso de flagrante delito ou por ordem escrita e fundamentada de autoridade judiciária competente: ninguém será preso senão em flagrante delito ou por ordem escrita e fundamentada de autoridade judiciária competente[...].

5) Comunicação imediata da prisão e do local onde se encontre o preso para o juiz competente e à família daquele ou pessoa por ele indicada: a prisão de qualquer pessoa e o local onde se encontre serão comunicados imediatamente ao juiz e à família do preso ou à pessoa por ele indicada.

6) Relaxamento imediato e ex-ofício da prisão ilegal: a "prisão ilegal será imediatamente relaxada pela autoridade judiciária". Exceção ao princípio da provocação jurisdicional, cabendo até habeas corpus de ofício. ${ }^{12}$

7) Proibição de prisão por divida: não haverá prisão civil por dívida, salvo a do responsável pelo inadimplemento voluntário e inescusável de obrigação alimentícia e a do depositário infiel.

8) Segurança pessoal: a segurança pessoal dos brasileiros e dos estrangeiros residentes no País é compromisso solene do Estado Nacional e está garantida tanto no preâmbulo quanto no

11 Constituição Federal, arts. $1^{\circ}$, incisos II e III, e $4^{\circ}$, inciso II.

12 CORRÊA, Plínio de Oliveira. O Habeas Corpus de Ofício. Revista de Informação Legislativa, Brasília, n. 59, p. 157 e ss. 
caput do artigo $5^{\circ}$ da nossa Constituição Federal, sendo, pois, direito subjetivo público, de eficácia imediata, oponível contra o Estado pelo cidadão, para a sua garantia no convívio social. $\mathrm{Di}$ reito Comparado: Constituição Portuguesa, art. 27: "Todos têm direito à liberdade e à segurança"; Constituição Espanhola, art. 17: "Toda pessoa tem direito à liberdade e à segurança" .

9) Respeito à integridade moral e física do presidiário: é assegurado aos presos o respeito à integridade física $\mathrm{e}$ moral", bem como as condições adequadas previstas legalmente (cf. art. 88 da Lei $N .^{\circ} 7.210 / 84$, trancrito no item 12 deste estudo).

10) Identificação dos responsáveis por sua prisão elou interrogatório policial: o preso tem direito à identificação dos responsáveis por sua prisão ou por seu interrogatório policial.

11) Princípio da presunção de não culpabilidade: ninguém será considerado culpado até o trânsito em julgado de sentença penal condenatória. Direito Comparado: Constituição Portuguesa (art. 27, $n^{\circ} 2$ ), Constituição Italiana (art. 27), Declaração Universal dos Direitos do Homem (art.11, $\mathrm{n}^{\circ} 1$ ).

12) Cumprimento da pena em estabelecimento adequado: a pena será cumprida em estabelecimentos distintos, de acordo com a natureza do delito, a idade e o sexo do apenado; assim como as condições adequadas e previstas no citado art. 88 da Lei $N^{\circ} 7210 / 84$ : "O condenado será alojado em cela individual que conterá dormitório, aparelho sanitário e lavatório.

Parágrafo único. São requisitos básicos da unidade celular: a) salubrida- de do ambiente pela concorrência dos fatores de aeração, insolação e condicionamento térmico adequado à existência humana; b) área mínima de $6 \mathrm{~m}^{2}$ (seis metros quadrados)".

13) Respeito à mãe presidiária e aos seus filhos durante o período de amamentação: às presidiárias serão asseguradas condições para que possam permanecer com seus filhos durante o período de amamentação.

14) O preso será informado de seus direitos: o preso será informado de seus direitos, entre os quais o de permanecer calado, sendo-lhe assegurada a assistência da família e de advogado.

15) Proibição da tortura e de tratamento desumano ou degradante: ninguém será submetido à tortura nem a tratamento desumano ou degradante.

16) Liberdade provisória: ninguém será levado à prisão ou nela mantido quando a lei admitir a liberdade provisória. Presentes os requisitos extrínsecos, referidos no item 4 deste capítulo, há que atender aos requisitos intrínsecos: prova da existência do crime, indícios idôneos da sua autoria, enquadramento num dos casos do art. 312 do $\mathrm{CPP}$, necessidade, conveniência e respeito às garantias do preso (art. $88 \mathrm{da}$ Lei $N^{\circ} 7210 / 84$ ).

17) Proibição das provas ilícitas: são inadmissíveis, no processo, as provas obtidas por meios ilícitos, nem os frutos da árvore proibida.

18) A publicidade do processo: a lei só poderá restringir a publicidade dos atos processuais quando a defesa da intimidade ou o interesse social o exigirem. Mirabeau, na Assembléia Constituinte Francesa de 1789: Donnez-moi 
le juge que vous voudrez: partial, corrupt, mon ennemi même, si vous voulez, peu m'importe pourvu qu'il ne puisse rien faire qu'à la face du public (Dêem-me o juiz que quiserem: parcial, corrupto, até mesmo inimigo meu, se quiserem, pouco me importa desde que ele não possa fazer nada a não ser em face do público).

19) O Princípio da ampla defesa (técnica e autodefesa): aos litigantes, em processo judicial ou administrativo, e aos acusados em geral são assegurados o contraditório e ampla defesa, com os meios e recursos a ela inerentes.

20) Fundamentação das decisões: todos os julgamentos dos órgãos do Poder Judiciário serão públicos, e fundamentadas todas as decisões, sob pena de nulidade, podendo a lei, se o interesse público o exigir, limitar a presença, em determinados atos, às próprias partes e a seus advogados, ou somente a estes.

21) Recursos essenciais para o duplo grau de jurisdição: aos litigantes, em processo judicial ou administrativo, são assegurados os recursos inerentes à sua defesa.

22) Princípios do promotor natural e do juiz natural: ninguém será processado nem sentenciado senão pela autoridade competente.

23) Proibição do juízo de exceção: não haverá juízo ou tribunal de exceção.

24) Ação de habeas corpus: conceder-se-á habeas corpus sempre que alguém sofrer ou se achar ameaçado de sofrer violência ou coação em sua liberdade de locomoção, por ilegalidade ou abuso de poder. CPP, art. 648: a coação considerar-se-á ilegal (exemplificativamente): I - quando não houver justa causa; II - quando alguém estiver preso por mais tempo do que determina a lei; III - quando quem ordenar a coação não tiver competência para fazê-lo; IV-quando houver cessado o motivo que autorizou a coação; $V-$ quando não for alguém admitido a prestar fiança, nos casos em que a lei a autoriza; VI - quando o processo for manisfestamente nulo; VII - quando extinta a punibilidade.

25) Habeas data: conceder-se-á habeas data: a) para assegurar o conhecimento de informações relativas à pessoa do impetrante paciente, constantes de registros ou bancos de dados de entidades governamentais ou de caráter público; b) para retificação de dados, quando não se prefira fazê-lo por processo sigiloso, judicial ou administrativo.

26) Revisão criminal: a lei penal não retroagirá, salvo para beneficiar o réu; o Estado indenizará o condenado por erro judiciário, assim como o que ficar preso além do tempo fixado na sentença. $O$ instituto da revisão criminal está regulado no Código de Processo Penal, cabendo transcrever, exemplificativamente, o seu artigo 621: A revisão dos processos findos será admitida: I quando a sentença condenatória for contrária ao texto expresso da lei penal ou à evidência dos autos; II - quando a sentença condenatória se fundar em depoimentos, exames ou documentos comprovadamente falsos; III - quando, após a sentença, se descobrirem novas provas de inocência do condenado ou 
de circunstância que determine ou autorize diminuição especial da pena. Súmula 393 do STF: Para requerer revisão criminal, o condenado não é obrigado a recolher-se à prisão.

27) Assistência jurídica aos necessitados: o Estado prestará assistência jurídica integral e gratuita aos que comprovarem insuficiência de recursos; Lei $\mathrm{N}^{\circ} 1.060 / 50$.

28) Indenização por erro judiciário ou excesso de prazo na prisão: o Estado indenizará o condenado por erro judiciário, assim como o que ficar preso além do tempo fixado pela sentença ou que resultar de prisão ilegítima.

29) Devido processo legal: ninguém será privado da liberdade ou de seus bens sem o devido processo legal.

30) Tribunal do Júri: é reconhecida a instituição do júri, com a organização que lhe der a lei, assegurados: a) a plenitude de defesa; b) o sigilo das votações; c) a soberania dos veredictos; d) a competência para o julgamento dos crimes dolosos contra a vida; artigo 464 do CPP: Formado o conselho, o juiz, levantando-se, e com ele todos os presentes, fará aos jurados a seguinte exortação: Em nome da lei, concito-vos a examinar com imparcialidade esta causa e a proferir a vossa decisão, de acordo com a vossa consciência e os ditames da justiça. Os jurados, nominalmente chamados pelo juiz, responderão: Assim o prometo.

31) Gratuidade das ações de habeas corpus, habeas data e os atos necessários ao exercício da cidadania: são gratuitas as ações de habeas corpus e habeas data, e, na forma da lei, os atos necessários ao exercício da cidadania.
32) Direito à informação e de petição junto aos Órgãos Públicos: todos têm direito a receber dos órgãos públicos informações de seu interesse particular, ou de interesse coletivo ou geral, que serão prestadas no prazo da lei, sob pena de responsabilidade, ressalvadas aquelas cujo sigilo seja imprescindível à segurança da sociedade e do Estado. Lei No 9.051/95.

33) Proibição de extradição de brasileiro, de naturalizado e suas exceções: nenhum brasileiro será extraditado, salvo o naturalizado, em caso de crime comum praticado antes da naturalização, ou de comprovado envolvimento em tráfico ilícito de entorpecentes e drogas afins na forma da lei.

34) Proibição de extradição de estrangeiro por crime político ou de opinião: não será concedida a extradição de estrangeiro por crime político ou de opinião.

35) Provocação Jurisdicional mediante ação penal privada subsidiária: será admitida ação privada nos crimes de ação pública, se esta não for intentada no prazo legal; Código de Processo Penal, art. 29, a): Será admitida ação privada nos crimes de ação pública, se esta não for intentada no prazo legal, cabendo ao Ministério Público aditar a queixa, repudiá-la e oferecer denúncia substitutiva, intervir em todos os termos do processo, fornecer elementos de prova, interpor recurso e, a todo tempo, no caso de negligência do querelante, retomar a ação como parte principal; b) art. 46: O prazo para oferecimento da denúncia, estando o réu preso, será de 5 (cinco) dias, contado da data em que o órgão do Ministério Público receber os autos do inquérito po- 
licial, e de 15 (quinze) dias, se o réu estiver solto ou afiançado. No último caso, se houver devolução do inquérito à autoridade policial (art. 16), contarse-á o prazo da data em que o órgão do Ministério Público receber novamente os autos. § $1^{\circ}$. Quando o Ministério Público dispensar o inquérito policial, o prazo para o oferecimento da denúncia contar-se-á da data em que tiver recebido as peças de informações ou a representação. $\S 2^{\circ}$. O prazo para o aditamento da queixa será de 3 (três) dias, contado da data em que o órgão do Ministério Público receber os autos, e, se este não se pronunciar dentro do tríduo, entender-se-á que não tem o que aditar, prosseguindo-se nos demais termos do processo.

As normas definidoras dos direitos fundamentais, aqui referidos, têm, por disposição constitucional, aplicação imediata (art. $5^{\circ}, \S 1^{\circ}$ ) e não excluem outras garantias decorrentes do regime democrático e dos princípios adotados pela nossa Lei Maior (art. $5^{\circ}, \S 2^{\circ}$ ).

\section{CONVENÇÃO AMERICANA SOBRE DIREITOS HUMANOS}

Coincidentemente, a grande maioria das garantias individuais asseguradas na Constituição Brasileira de 1988 também consta da Convenção Americana sobre Direitos Humanos, ou melhor, muitas delas foram dali transpostas para a nossa Constituição, pois esta é posterior àquela em 19 anos. Em outras palavras, estes direitos, embora muitos já figurassem nas constituições anteriores (1824, 1891, 1934, 1937, 1946, 1967, 1969), foram valorados, primeiramente, na citada Con- venção, onde contou com a integral aprovação da representação brasileira e, depois, transcritos para a nossa carta política, inobstante a ratificação daquela, por nós, só tenha ocorrido 22 anos após, isto é, em 6 de novembro de 1992.

Por estarem, ditos direitos, intimamente interligados não apenas com a sua consolidação no plano internacional, mas internamente com a recepção legal decorrente do citado Decreto $\mathrm{N}^{\circ}$ $678 / 92$, que os integrou ao nosso ordenamento jurídico, - merece destaque o preceito do parágrafo $2^{\circ}$ do já mencionado artigo $5^{\circ}$ da Constituição Federal: "Os direitos e garantias expressos nesta Constituição não excluem outros decorrentes do regime e dos princípios por ela adotados, ou dos tratados internacionais em que a República Federativa do Brasil seja parte" (g.n.).

Feitas estas observações, convém referir os princípios do Pacto de São José da Costa Rica, incidentes no ordenamento jurídico dos Estados-membros.

Os signatários da citada Convenção iniciaram sua obra declarando estes dois solenes compromissos institucionais:

Os Estados-partes nesta Convenção comprometem-se a respeitar os direitos e liberdades nela reconhecidos e a garantir seu livre e pleno exercício a toda pessoa que esteja sujeita à sua jurisdição, sem discriminação alguma por motivo de raça, cor, sexo, idioma, religião, opiniões políticas ou de qualquer outra natureza, origem nacional ou social, posição econômica, nascimento ou qualquer outra condição social. Para os efeitos desta Convenção, pessoa é todo ser humano. 
Se o exercício dos direitos e liberdades individuais ainda não estiver garantido por disposições legislativas ou de outra natureza, os Estados-partes comprometem-se a adotar, de acordo com as suas normas constitucionais e com as disposições desta Convenção, as medidas legislativas ou de outra natureza que forem necessárias para tornar efetivos tais direitos e liberdades.

A par desses dois importantíssimos compromissos, cabe destacar, de forma objetiva, os seguintes postulados a serem observados para o aperfeiçoamento do Direito Penal e do Processo Penal:

\subsection{Direito à vida ${ }^{13}$}

1 Toda pessoa tem o direito de que se respeite sua vida. Esse direito deve ser protegido pela lei e, em geral, desde o momento da concepção. Ninguém pode ser privado da vida arbitrariamente. 2. Nos países que não houverem abolido a pena de morte, esta só poderá ser imposta pelos delitos mais graves, em cumprimento de sentença final de tribunal competente e em conformidade com lei que estabeleça tal pena, promulgada antes de haver o delito sido cometido. Tampouco se estenderá sua aplicação a delitos aos quais não se aplique atualmente. 3. Não se pode restabelecer a pena de morte nos Estados que a hajam abolido. 4 . Em nenhum caso pode a pena de morte ser aplicada por delitos políticos, nem por delitos co- muns conexos com delitos políticos. 5 . Não se deve impor a pena de morte a pessoa que, no momento da perpetração do delito, for menor de dezoito anos, ou maior de setenta, nem aplicála a mulher em estado de gravidez. 6 . Toda pessoa condenada à morte tem direito a solicitar anistia, indulto ou comutação da pena, os quais podem ser concedidos em todos os casos. Não se pode executar a pena de morte enquanto o pedido estiver pendente de decisão ante a autoridade competente. ${ }^{14}$

\subsection{Direito à integridade pessoal ${ }^{15}$}

1. Toda pessoa tem o direito de que se respeite sua integridade física, psíquica e moral. 2. Ninguém deve ser submetido a torturas, nem a penas ou tratos cruéis, desumanos ou degradantes. Toda pessoa privada da liberdade deve ser tratada com o respeito devido à dignidade inerente ao ser humano. 3. A pena não pode passar da pessoa do delinqüente. 4 . Os processados devem ficar separados dos condenados, salvo em circunstâncias excepcionais, e ser submetidos a tratamento adequado à sua condição de pessoas não condenadas. 5. Os menores, quando puderem ser processados, devem ser separados dos adultos e conduzidos a tribunal especializado, com maior rapidez possível, para seu tratamento. 6. As penas privativas da liberdade devem ter por finalidade essencial a reforma e a readaptação social dos condenados.

$13 \operatorname{art.} 4^{\circ}$.

14 CORRÊA, Plínio de Oliveira. Ação Penal Originária. Porto Alegre, Síntese 2001. p. 86. 15 Art. $5^{\circ}$. 


\subsection{Proibição da escravidão e/ou servidão ${ }^{16}$}

Não constituem trabalhos forçados ou obrigatórios para os efeitos deste artigo: a) os trabalhos ou serviços normalmente exigidos de pessoa reclusa em cumprimento de sentença ou resolução formal expedida pela autoridade judiciária competente. Tais trabalhos ou serviços devem ser executados sob a vigilância e controle das autoridades públicas, e os indivíduos que os executarem não devem ser postos à disposição de particulares, companhias ou pessoas jurídicas de caráter privado.

\subsection{Direito à liberdade pessoal ${ }^{17}$}

1. Toda pessoa tem direito à liberdade e à segurança pessoais. 2. Ninguém pode ser privado de sua liberdade física, salvo pelas causas e nas condições previamente fixadas pelas constituições políticas dos Estados-partes ou pelas leis de acordo com elas promulgadas. 3 . Ninguém pode ser submetido a detenção ou encarceramento arbitrários. 4. Toda a pessoa detida ou retida deve ser informada das razões da sua detenção e notificada, sem demora, da acusação ou acusações formuladas contra ela. 5. Toda pessoa detida ou retida deve ser conduzida, sem demora, à presença de um juiz ou outra autoridade autorizada pela lei a exercer funções judiciais e tem direito a ser julgada dentro de um prazo razoável ou a ser posta em liberdade, sem prejuízo de que prossiga o processo. Sua liberdade pode ser condicionada a garantias que assegurem o seu comparecimento em juízo. 6. Toda pessoa privada da liberdade tem direito a recorrer a um juiz ou tribunal competente, a fim de que este decida, sem demora, sobre a legalidade de sua prisão ou detenção e ordene sua soltura se a prisão ou a detenção forem ilegais. Nos Estados-partes cujas leis prevêem que toda pessoa que se vir ameaçada de ser privada de sua liberdade tem direito a recorrer a um juiz ou tribunal competente a fim de que este decida sobre a legalidade de tal ameaça, tal recurso não pode ser restringido nem abolido. O recurso pode ser interposto pela própria pessoa ou por outra pessoa. 7. Ninguém deve ser detido por dívida. Este princípio não limita os mandados de autoridade judiciária competente expedidos em virtude de inadimplemento de obrigação alimentar.

\subsection{Garantias judiciais ${ }^{18}$}

1. Toda pessoa tem direito a ser ouvida, com as devidas garantias e dentro de um prazo razoável, por um juiz ou tribunal competente, independente e imparcial, estabelecido anteriormente por lei, na apuração de qualquer acusação penal formulada contra ela, ou para que se determinem seus direitos ou obrigações de natureza civil, trabalhista, fiscal

16 Art. $6^{\circ}$.

17 Art. $7^{\circ}$.

18 Art. $8^{\circ}$. 
ou de qualquer outra natureza. 2. Toda pessoa acusada de delito tem direito a que se presuma sua inocência enquanto não se comprove legalmente sua culpa. Durante o processo, toda pessoa tem direito, em plena igualdade, às seguintes garantias mínimas: a) direito do acusado de ser assistido gratuitamente por tradutor ou intérprete, se não compreender ou não falar o idioma do juízo ou tribunal; b) comunicação prévia e pormenorizada ao acusado da acusação formulada; c) concessão ao acusado do tempo e dos meios adequados para a preparação de sua defesa; d) direito do acusado de defender-se pessoalmente ou de ser assistido por um defensor de sua escolha $\mathrm{e}$ de comunicar-se, livremente e em particular, com seu defensor; e) direito irrenunciável de ser assistido por um defensor proporcionado pelo Estado, remunerado ou não, segundo a legislação interna, se o acusado não se defender por ele próprio nem nomear defensor dentro do prazo estabelecido pela lei; $f$ ) direito de defesa de inquirir as testemunhas presentes no tribunal e de obter o comparecimento, como testemunhas ou peritos, de outras pessoas que possam lançar luz sobre os fatos; g) direito de não ser obrigado a depor contra si mesma, nem a declarar-se culpada; e h) direito de recorrer da sentença para juiz ou tribunal superior. 3 . A confissão do acusado só é válida se feita sem coação de nenhuma natureza. 4 . $O$ acusado por sentença passada em julgado não poderá ser submetido a novo processo pelos mesmos fa- tos. 5 . O processo penal deve ser público, salvo no que for necessário para preservar os interesses da justiça.

\subsection{Princípios da legalidade e da retroatividade $^{19}$}

Ninguém pode ser condenado por ações ou omissões que, no momento em que forem cometidas, não sejam delituosas, de acordo com o direito aplicável.

Tampouco se pode impor pena mais grave que a aplicável no momento da perpetração do delito. Se depois da perpetração do delito a lei dispuser a imposição de pena mais leve, o delinqüente será por isso beneficiado.

\subsection{Direito à indenizaçãa $0^{211}$}

Toda pessoa tem direito de ser indenizada conforme a lei, no caso de haver sido condenada em sentença passada em julgado, por erro judiciário.

\subsection{Direito de circulação e de residência ${ }^{21}$}

1. Toda pessoa que se ache legalmente no território de um Estado tem direito de circular nele e de nele residir em conformidade com as disposições legais. 2 . Toda pessoa tem direito de sair livremente de qualquer país, inclusive do próprio. 7.Toda pessoa tem o direito de buscar e receber asilo em território estrangeiro, em caso de perseguição por delitos políticos ou comuns conexos com delitos po-

19 Art. $9^{\circ}$.

20 Art. 10.

21 Art. 22. 
líticos e de acordo com a legislação de cada Estado e com os convênios internacionais. 8. Em nenhum caso o estrangeiro pode ser expulso ou entregue a outro país, seja ou não de origem, onde seu direito à vida ou à liberdade pessoal esteja em risco de violação por causa da sua raça, nacionalidade, religião, condição social ou de suas opiniões políticas.

\subsection{Igualdade perante a lei ${ }^{22}$}

Todas as pessoas são iguais perante a lei. Por conseguinte, têm direito, sem discriminação, a igual proteção da lei.

\subsection{Direito à proteção judicial ${ }^{23}$}

1. Toda pessoa tem direito a um recurso simples e rápido ou a qualquer outro recurso efetivo, perante os juízes ou tribunais competentes, que a protejam contra atos que violem seus direitos fundamentais reconhecidos pela Constituição, pela lei ou pela presente Convenção, mesmo quando tal violação seja cometida por pessoas que estejam atuando no exercício de suas funções oficiais. 2. Os Estados-partes comprometem-se: a) a assegurar que a autoridade competente prevista pelo sistema legal do Estado decida sobre os direitos de toda pessoa que interpuser tal recurso; b) a desenvolver as possibilidades de recurso judicial; ec) a assegurar o cumprimento, pelas autoridades competentes, de toda decisão em que se tenha considerado procedente recurso.

\subsection{Presunção de Inocência e Recursos $^{24}$}

1. Toda pessoa acusada de delito tem direito a que se presuma sua inocência enquanto não se comprove legalmente sua culpa (Antecedente: DUDH, art. $11, \mathrm{n}^{\circ} 1$ ). Durante o processo, toda pessoa tem direito, em plena igualdade, às seguintes garantias mínimas: [...] h) direito de recorrer da sentença para juiz ou tribunal superior. 2. Para que uma petição ou comunicação apresentada de acordo com os arts. 44 ou 45 seja admitida pela Comissão será necessário: a) que hajam sido interpostos e esgotados os recursos da jurisdição interna, de acordo com os princípios de direito internacional geralmente reconhecidos.

\subsection{Normas de interpretação ${ }^{25}$}

Nenhuma disposição desta Convenção pode ser interpretada no sentido de: a) permitir a qualquer dos Estados-partes, grupo ou pessoa, suprimir o gozo e exercício dos direitos e liberdades reconhecidos na Convenção ou limitá-los em maior medida do que a nela prevista; b) limitar o gozo e exercício de qualquer direito ou liberdade que possam ser reconhecidos de acordo com as leis de qualquer dos Estados-partes ou de acordo com outra convenção que seja parte um dos referidos Estados; c) excluir outros direitos e garantias que são

\section{Art. 24.}

\section{Art. 25.}


inerentes ao ser humano ou que decorrem da forma democrática representativa de governo; e) excluir ou limitar o efeito que possam produzir a Declaração Americana dos Direitos e Deveres do Homem e outros atos internacionais da mesma natureza.

\subsection{Alcance das restrições ${ }^{26}$}

As restrições permitidas, de acordo com esta Convenção, ao gozo e exercício dos direitos e liberdades nela reconhecidos, não podem ser aplicadas senão de acordo com leis que forem promulgadas por motivo de interesse geral e com o propósito para o qual houverem sido estabelecidas.

\subsection{Correlação entre deveres e direitos ${ }^{27}$}

1. Toda pessoa tem deveres para com a família, a comunidade e a humanidade. 2. Os direitos de cada pessoa são limitados pelos direitos dos demais, pela segurança de todos e pelas justas exigências do bem comum, numa sociedade democrática.

\subsection{5 Órgãos garantidores dos direitos humanos ${ }^{28}$}

São competentes para conhecer dos assuntos relacionados com o cumprimento dos compromissos assumidos pelos Estados-partes nesta Convenção: (a) a Comissão Interamericana de Direitos Humanos, denominada simplificadamente Comissão; e (b) a Corte In- teramericana de Direitos Humanos, denominada Corte.

A Comissão, composta de sete membros, tem a função principal de promover a observância e a defesa dos direitos humanos e, no exercício do seu mandato, tem as seguintes funções e atribuições: a) estimular a consciência dos direitos humanos nos povos da América; b) formular recomendações aos governos dos Estados-membros, quando considerar conveniente, no sentido de que adotem medidas progressivas em prol dos direitos humanos no âmbito de suas leis internas e seus preceitos constitucionais, bem como disposições apropriadas para promover o devido respeito a esses direitos; c) preparar os estudos ou relatórios que considerar convenientes para o desempenho de suas funções; d) solicitar aos governos dos Estados-membros que lhe proporcionem informações sobre medidas que adotarem em matéria de direitos humanos; e) atender às consultas que, por meio da Secretaria-Geral da Organização dos Estados Americanos, lhe formularem os Estados-membros sobre questões relacionadas com os direitos humanos e, dentro de suas possibilidades, prestar-lhes assessoramento que eles lhe solicitarem; f) atuar com respeito às petições e outras comunicações, no exercício de sua autoridade, de conformidade com o disposto nos arts. 44 a 51 desta Convenção; e g) apresentar um relatório anual à Assembléia-Geral da Organização dos Estados Americanos. 
Os Estados-partes obrigam-se a proporcionar à Comissão as informações que esta lhes solicitar sobre a maneira pela qual o seu direito interno assegura a aplicação efetiva de quaisquer disposições desta Convenção.

A Corte compor-se-á de juízes nacionais dos Estados-membros da Organização, eleitos a título pessoal dentre juristas da mais alta autoridade moral, de reconhecida competência em matéria de direitos humanos, que reúnam as condições requeridas para o exercício das mais elevadas funções judiciais, de acordo com a lei do Estado do qual sejam nacionais, ou do Estado que os propuser como candidatos. 2. Não deve haver dois juízes da mesma nacionalidade.

\subsection{Legitimidade para provocar a Comissão e a Corte; outras formalidades procedimentais ${ }^{29}$}

Qualquer pessoa ou grupo de pessoas, ou entidade não governamental legalmente reconhecida em um ou mais Estadosmembros da Organização, pode apresentar à Comissão petições que contenham denúncias ou queixas de violação desta Convenção por um Estado-parte.

1. Para que uma petição ou comunicação apresentada de acordo com os arts. 44 ou 45 seja admitida pela Comissão será necessário: a) que hajam sido interpostos e esgotados os recursos da jurisdição interna, de acordo com os princípios de direito internacional geralmente reconhecidos; b) que seja apresentada dentro do prazo de seis meses, a partir da data em que o presumido prejudicado em seus direitos tenha sido notificado da decisão definitiva; c) que a matéria da petição ou comunicação não esteja pendente de outro processo de solução internacional; e d) que, no caso do art. 44 , a petição contenha o nome, a nacionalidade, a profissão, o domicílio e a assinatura da pessoa ou pessoas ou do representante legal da entidade que submeter a petição. 2. As disposições das alíneas $a$ e $b$ do inciso 1 deste artigo não se aplicarão quando: a) não existir, na legislação interna do Estado de que se tratar, o devido processo legal para a proteção do direito ou direitos que se alegue tenham sido violados; b) não se houver permitido ao presumido prejudicado em seus direitos o acesso aos recursos da jurisdição interna, ou houver sido ele impedido de esgotá-los; e c) houver demora injustificada na decisão sobre mencionados recursos.

A Comissão declarará inadmissível toda petição ou comunicação apresentada de acordo com os arts. 44 ou 45 quando: a) não preencher algum dos requisitos estabelecidos no art. 46 ; b) não expuser fatos que caracterizem violação dos direitos garantidos por esta Convenção; c) pela exposição do próprio peticionário ou do Estado, for manifestante infundada a petição ou comunicação ou for evidente sua total improcedência; ou d) for substancialmente reprodução de petição ou comunicação anterior, já examinada pela Comissão ou por outro organismo internacional. 
1. Somente os Estados-partes e a Comissão têm direito de submeter caso à decisão da Corte. 2. Para que a Corte possa conhecer de qualquer caso, é necessário que sejam esgotados os processos previstos nos arts. 48 a 50 .

\subsection{Conseqüências da violação dos direitos humanos e medidas provisórias ${ }^{30}$}

1. Quando decidir que houve violação de um direito ou liberdade protegido nesta Convenção, a Corte determinará que se assegure ao prejudicado o gozo do seu direito ou liberdade violados. Determinará, também, se isso for procedente, que sejam reparadas as consequiências da medida ou situação que haja configurado a violação desses direitos, bem como o pagamento de indenização justa à parte lesada. 2. Em casos de extrema gravidade e urgência, e quando se fizer necessário evitar danos irreparáveis às pessoas, a Corte, nos assuntos de que estiver conhecendo, poderá tomar as medidas provisórias que considerar pertinentes. Se se tratar de assuntos que ainda não estiverem submetidos ao seu conhecimento, poderá atuar a pedido da Comissão.

Pontualmente, porém, esta relevante Convenção Internacional foi referendada internamente pelo Congresso $\mathrm{Na}$ cional Brasileiro (sessão conjunta do Senado e da Câmara dos Deputados), que autorizou ao Poder Executivo (art.
84, VIII, C.F.) a recepcioná-la mediante a edição do já citado Decreto $\mathrm{N}^{\circ} 678 /$ 92 , que a promulgou inserindo esta imperativa determinação interna: deverá ser cumprida tão inteiramente como nela se contém.

No entanto, os direitos humanos somente obtiveram um instrumento jurídico eficaz a partir da recomendação emitida pela Assembléia Geral da ONU aos Estados-membros, em 16 de dezembro de 1966 (que entrou em vigor a 23 de março de 1976, de acordo com o disposto no seu art. 49), de que assinassem e ratificassem dois Pactos Internacionais: um relativo aos chamados direitos civis e políticos, e outro, aos denominados direitos econômicos, sociais e culturais.

Por conseguinte, como explica Gustavo Pinard, ${ }^{31}$ o Pacto de São José da Costa Rica distribui seus oitenta e dois artigos em três partes: na primeira, abriga os deveres dos Estados e os direitos protegidos, ou seja, os direitos humanos, aí compreendidos os direitos civis, políticos, econômicos, sociais e culturais, havendo disciplina, inclusive, para as circunstâncias extraordinárias que determinarem a suspensão desses direitos, bem assim para a escorreita relação dos direitos e deveres; na segunda, acham-se organizados os dispositivos de proteção dos direitos, a cargo da Comissão e da Corte Interamericana de Direitos Humanos; e na terceira parte contempla as disposições gerais e transitórias.

\section{Art. 63.}

31 PINARD, Gustavo. Mercosur y los Tratados Internacionales. Buenos Aires: Ciudad Argentina, 1997.; PINARD, Gustavo. Los Derechos Humanos en las Constituciones del Mercosur. Buenos Aires: ciudad Argentina, 1996. 


\section{O PACTO, O BRASIL E OS GUARDIÕES DOS DIREITOS HUMANOS}

Mas aquele importantíssimo documento, antes referido e mais conhecido como Pacto de São José da Costa Rica, só passou a vigorar no plano internacional no dia 18 de julho de 1978 , na conformidade do que dispõe o parágrafo $2^{\circ}$ do seu artigo 74 , ou seja, quando atingiu o número mínimo de onze Estados membros que depositaram formalmente suas respectivas ratificações.

Assim, até a presente data, eis os Estados-partes, originários das Américas do Sul, Central e do Norte, que ratificaram a aludida Convenção: Argentina, Barbados, Bolívia, Brasil, Chile, Colômbia, Costa Rica, Equador, El Salvador, Grenada, Guatemala, Haiti, Honduras, Jamaica, México, Nicarágua, Panamá, Paraguai, Peru, República Dominicana, Suriname, Uruguai, Venezuela. Os Estados Unidos e o Canadá, apesar de terem firmado o Pacto, não o ratificaram. E sete Estados-partes (Barbados, Brasil, Grenada, Haiti, Jamaica, México e República Dominicana), lamentavelmente ainda não reconheceram a competência contenciosa da Corte..$^{32}$

Entre nós, ela só entrou em vigor, repercutindo nas relações internacionais, no dia 25 de setembro de 1992 , por ocasião da apresentação da Carta Brasileira de Ratificação junto à Secretaria-Geral da Organização dos Estados Americanos (OEA) e com a formal recepção pelo Decreto Presidencial $N^{\circ}$ 678, de 06 de novembro do mesmo ano, decorrente de autorização do Congresso Nacional. ${ }^{33}$

Todos os países, em regra, de uma ou de outra forma têm dedicado internamente atenção especial à matéria, elegendo garantias individuais em suas Constituições e na legislação infraconstitucional.

De outra parte, em 1948, dois ilustres brasileiros se destacaram no cenário internacional, projetando historicamente o nosso país: os gaúchos Osvaldo Aranha e João Neves da Fontoura, nascidos, respectivamente, no Alegrete e em Cachoeira do Sul. O primeiro, presidiu a Assembléia Geral da Organização das Nações Unidas, que proclamou a Declaração Universal dos Direitos Humanos; o segundo, presidiu a Delegação Brasileira na mesma Assembléia Internacional.

Foi nesta posição de liderança da Delegação Brasileira que João Neves da Fontoura projetou o Estado Brasileiro com a idéia de constituir a Corte Interamericana de Direitos Humanos, que, depois, se efetivou na Convenção Americana de 1969. Para tanto, basta lembrar que foi a Delegação que repre-

32 A Mensagem Presidencial $N^{\circ} 621$, de 28.11.85, que submeteu o texto do mencionado Pacto à aprovação do Congresso Nacional, assim se refere, pontualmente: "No tocante às cláusulas facultativas contempladas no parágrafo $1^{\circ}$ do Artigo 45 - referente à competência da Comissão Interamericana de Direitos Humanos (CIDH) para examinar queixas apresentadas por outros Estados sobre o não cumprimento das obrigações - e no parágrafo $1^{\circ}$ do Artigo 62 - relativo à jurisdição obrigatória da Corte - não é recomendável, na presente etapa, a adesão do Brasil".

33 CORRÊA. Ação Penal... p. 106, 143 et seqs. 
sentou o Brasil na IX Conferência Internacional Americana, em dezembro de 1948, que propôs a criação de uma Corte Interamericana de Direitos Humanos.

A feliz proposta brasileira - ressaltando a necessidade da criação de um órgão judicial internacional para tornar adequada e eficaz a proteção jurídica dos direitos humanos internacionalmente reconhecidos ${ }^{34}$ - foi aprovada pela Resolução XXI da Conferência de Bogotá, figurando da respectiva Exposição de Motivos, que, há mais de meio século alertou para as possíveis arbitrariedades insuperáveis de que era vítima o indivíduo, cometidas pelas próprias autoridades governamentais. ${ }^{35}$

Em 1968, ao ensejo do transcurso do vigésimo aniversário da Declaração Universal dos Direitos Humanos, foi adotada a Proclamação de Teerã sobre Direitos Humanos pelo plenário da I Conferência Mundial de Direitos Humanos da ONU.

No ano seguinte, afinal, foi aprovada a Convenção Americana sobre Direitos Humanos de São José da Costa
Rica, pela qual se instituiu a anunciada Corte Interamericana.

Por outro lado, os Guardiões da observância dos direitos fundamentais da pessoa humana no nosso Ordenamento Jurídico são de duas ordens:

INTERNAMENTE, o Estado Brasileiro através dos órgãos da Administração Pública, em geral, agindo diretamente, e os órgãos específicos do Poder Judiciário, compostos de juizes e tribunais, atuando mediante o princípio da provocação jurisdicional; ${ }^{36}$

EXTERNAMENTE, a Organização dos Estados Americanos (OEA), com base na respectiva Convenção de 22 de novembro de 1969 , que instituiu, para tanto, não só a Comissão de Direitos Humanos, constituída de sete membros, mas também a Corte Interamericana de Direitos Humanos, ${ }^{37}$ formada por sete juízes, escolhidos, estes para um mandato de seis anos, podendo ser reeleitos uma vez, e aqueles para um período de quatro anos, admitindo-se também uma reeleição, - dentre juristas da mais alta autoridade moral e de reconhecida competência em matéria de direitos humanos.

34 IX Conferência Internacional Americana - 1948, Actas y Documentos, vol. V, Bogotá, M.R.E. de Colombia, 1953, Documento CB-125/C.VI-6, p. 464; e Vol. VI op. cit., p. 353 (Resolução XXXI da Conferência).

35 Proposta, in Documento C-125/C.VI-6, idem, Vol. V, p. 464-465.

36 CORRÊA. A Provocação...

37 Esta Comissão exerce no plano internacional função correspondente à do Ministério Público no âmbito interno de cada Estado. Assim entendeu a Corte na sua primeira decisão (Acórdão $N^{\circ}$ G101/81, de 13.11.81, caso Viviana Gallardo e Outros), considerando as funções da Comissão como de fiscal dos direitos fundamentais e de acusador público, confiadas ao Ministério Público dos Estados Latino-Americanos. Mutatis mutandis, a omissão da Comissão poderá ensejar atuação da parte interessada, promovendo provocação subsidiária, prevista não só na nossa legislação ordinária (CPP, art. 29), mas também na Constituição Federal (art. $5^{\circ}$, LIX). 
Posteriormente, porém, com a promulgação da nossa Carta Política de 1988, o Estado Brasileiro também assumiu o expresso compromisso constitucional de reger suas relações internacionais observando o princípio da "prevalência dos direitos humanos" (CF, art. $4^{\circ}$, II).

No entanto, para que, no âmbito internacional, não apenas a Comissão de Direitos Humanos, como também a Corte Interamericana de Direitos $\mathrm{Hu}$ manos possam agir como guardiãs efetivas da observância e da garantia desses direitos fundamentais, entre nós, é necessário algo mais que a simples ratificação ou adesão à Carta, que já ocorreu: é preciso que o Estado-parte, nos termos dos seus artigos 45 e 62, faça formal declaração de "que reconhece como obrigatória, de pleno direito e sem convenção especial, a competência da Corte em todos os casos relativos à interpretação ou aplicação desta Convenção". Dita declaração pode ser apresentada incondicionalmente, ou sob condição de reciprocidade, por prazo determinado ou para casos especiais, inclusive retratar-se.

$\mathrm{E}$, ao que se sabe, tal ainda não fora feito pelo Estado Brasileiro, como Membro daquela Convenção. O que é lamentável para todos quantos aqui vivem, particularmente para os brasileiros de todas as regiões e especialmente para nós rio-grandenses-do-sul, de onde partiu a idéia da criação daquela Corte.

$\mathrm{Na}$ verdade, o Brasil só amadurecerá a sua política interna e externa dos direitos humanos, quando confiar na JUSTIÇA como Instituição e como valor, perdendo o medo e a insegurança de submeter essa política à apreciação da jurisdição internacional da Corte Interamericana dos Direitos Humanos, que tem como Presidente o eminente Brasileiro e insigne Jurista - Professor Antônio Augusto Cançado Trindade.

Os direitos fundamentais compreendem os direitos do homem e da mulher, sem excluir naturalmente os direitos dos seres que nos rodeiam e que formam o nosso meio ambiente.

\section{REFERÊNCIAS}

CÍCERO. De la République de Lois. s.l.: Garmier-Flammarion, 1965.

CORRÊA, Plínio de Oliveira. Ação Penal Originária. Porto Alegre, Síntese 2001.

Liberdade Individual nos Países do Mercosul. 2. ed. Porto Alegre: Livraria do Advogado, 1998. p. 21 et seq.

O Habeas Corpus de Ofício. Revista de Informação Legislativa, Brasília, $n^{\circ} .59$, p. 157 e ss.

A Provocação Jurisdicional, Porto Alegre: Editora da Universidade, 1978.

HELMONS, Marcus. Mélanges Offerts à Georges Levasseur: droit pénal, droit européen. Paris: Litec, 1992.

IMBERT, Jean. Les Droits de l'Homme en France. Paris: La Documentation Française, 1985. (Coleção Notes et Études Documentaires).

JOÃO XXIII. Encíclica Mater et Magistra, 1961.

PINARD, Gustavo. Los Derechos Humanos en las Constituciones del Mercosur. 
Buenos Aires: Ciudad Argentina, 1996. Mercosur y los Tratados Internacionales. Buenos Aires: Ciudad Argentina, 1997.

TRINDADE, Antônio Augusto Cançado. A Proteção Internacional dos Direitos
Humanos e o Brasil. 2. ed. s.1.: Humanidades.

ZAVASCKI, Teori Albino. Direitos Fundamentais de Terceira Geração. Revista da Faculdade de Direito da UFRGS, Porto Alegre, v.15, p. 227-231, 1998. 